\title{
PENGUNGKAPAN SUSTAINABILITY REPORT DAN \\ FAKTOR-FAKTOR YANG MEMPENGARUHINYA
}

\author{
Ardiani Ika Sulistyawati \\ Aprilia Qadriatin \\ Fakultas Ekonomi Universitas Semarang (USM)
}

Diterima: April 2018. Disetujui: Juli 2018. Dipublikasikan: Oktober 2018

\begin{abstract}
This research is motivated by the occurrence of a phenomenon where the Sustainability Report disclosure is still lacking. The purpose of this study was to analyze the role of the board of commissioners, audit committee, ROA, leverage, firm size on Sustainability Report disclosures. The sampling method used a purposive sampling technique. Samples were 39 companies in the 2010 to 2014 research period and obtained 195 data processed. This study uses logistick regression analysis tools. The results of the study show that the Board of Commissioners, Audit Committee, ROA and leverage have no effect on the Sustainability Report. While the size of the company influences the Sustainability Report. The Nagelkerke determination coefficient is 0.083 which means the board of commissioners variable, audit committee, ROA, leverage, and company size have an influence of $8.3 \%$ on the Sustainability Report, and the rest are influenced by other factors.
\end{abstract}

Keywords: board of commissioners, audit committee, ROA, leverage, company size and sustainability report

\begin{abstract}
ABSTRAK
Penelitian ini dilatar belakangi oleh terjadinya sebuah fenomena dimana pengungkapan Sustainability Report yang masih kurang. Tujuan penelitian ini adalah menganalisis peran dewan komisaris, komite audit, ROA, leverage, ukuran perusahaan terhadap pengungkapan Sustainability Report. Metode pengambilan sampel menggunakan teknik purposive sampling. Sampel sebanyak 39 perusahaan pada periode penelitian 2010 sampai 2014 dan diperoleh 195 data yang diolah. Penelitian ini menggunakan alat analisis regresi logistick. Hasil penelitian diperoleh bahwa Dewan Komisaris, Komite Audit, ROA dan leverage tidak berpengaruh terhadap Sustainability Report. Sedangkan ukuran perusahaan berpengaruh terhadap Sustainability Report. Koefisien determinasi Nagelkerke sebesar 0,083 yang berarti variabel dewan komisaris, komite audit, ROA, leverage, dan ukuran perusahaan berpengaruh $8,3 \%$ terhadap Sustainability Report, dan sisanya di pengaruhi faktor faktor lainnya.
\end{abstract}

Kata kunci: dewan komisaris, komite audit, ROA, leverage, ukuran perusahaan dan Sustainability Report

\section{PENDAHULUAN}

Laporan keberlanjutan (sustainability report) merupakan bentuk laporan yang bersifat sukarela (voluntary) sebagai bentuk tanggung jawab sosial dan lingkungan. Sustainability report sangat diperlukan agar stakeholders termasuk masyarakat mengetahui segala bentuk tanggung jawab perusahaan kepada masyarakat dan lingkungan. Secara definisi, sustainability report adalah praktek pengukuran dan pengungkapan dan upaya akuntabilitas dari kinerja organisasi dalam mencapai tujuan pembangunan berkelanjutan kepada para pemangku 
kepentingan baik internal maupun eksternal. Laporan berkelanjutan merupakan sebuah istilah umum yang dianggap sinonim dengan istilah lainnya untuk menggambarkan laporan mengenai dampak ekonomi, lingkungan, dan sosial (misalnya triple bottom line, laporan pertanggungjawaban perusahaan, dan lain sebagainya) (www.globalreporting.org).

Perusahaan hanya berorientasi pada maksimalisasi laba dan mengabaikan dampak lingkungan dan sosial. Saat paradigma bahwa perusahaan melalui kegiatan bisnis berusaha mencari keuntungan semata sudah usang. Nugroho (2009) kini tujuan bisnis tidak hanya mencari keuntungan (profit), tetapi juga tanggung jawab kepada masyarakat (people) dan bumi (planet). Ketiga hal tersebut dikenal dengan Tripple-P Bottom Line.

Perusahaan mulai menyadari untuk mengungkapkan sebuah laporan yang tidak hanya berpijak pada single bottom line, yaitu kondisi keuangan peusahaan saja tetapi berpijak pada tripple bottom line, yaitu selain informasi keuangan juga menyediakan informasi sosial, ekonomi, dan lingkungan, yang kemudian disebut dengan sustainability report. Sustainability report disusun oleh Global Reporting Initiative (GRI) yang bermarkas di Belanda. GRI dan pemegang otoritas lain di dunia, berusaha mengembangkan "framework for sustainability reporting", dan versi terakhir dari pedoman pelaporan yang telah dihasilkan dinamakan G3 Guidelines (Dilling, 2009).

Semakin lama jumlah organisasi-organisasi maupun perusahaan perusahaan global yang mengadopsi G3 Guidelines semakin menigkat. Perusahaan - perusahaan yang telah menerbitkan sustainability report berdasarkan G3 Guidelines disyaratkan memenuhi tipe - tipe standar pelaporan, yakni profil organisasi, indikator kinerja, dan pendekatan manajemen (GRI 2009B).

Kegiatan pengelolaan perusahaan saat ini tidak hanya berdasarkan aspek ekonomi tetapi juga mempertimbangkan aspek sosial. Sejak berkembangnya isu mengenai Corporate Social Responsibility (CSR) dan keberlanjutan (sustainability) perusahaan menjadi sorotan utama terhadap perannya terhadap lingkungan. Dikarenakan terjadi serangkaian tragedi lingkungan dan kemanusiaan di Indonesia, seperti kasus banjir lumpur panas oleh PT. Lapindo Brantas di Sidoarjo, Jawa Timur, pencemaran Teluk Buyat di Minahasa Selatan 
oleh PT.Newmont Minahasa Raya, konflik masyarakat Aceh dengan Exxon mobil yang mengelola gas bumi di Arun, serta masalah pemberdayaan masyarakat suku di wilayah pertambangan PT.Freeport di Papua.

Pengungkapan sustainability report di Indonesia sesuai dengan Peraturan Pemerintah diantaranya Undang-undang No. 23 Tahun 1997 mengenai lingkungan, Undang-undang No. 44 pasal 66 ayat 2 dan pasal 74 Tahun 2007 mengenai kewajiban tanggung jawab sosial perusahaan. Selain itu, Pernyataan Standar Akuntansi Keuangan (PSAK) No. 1 tentang tanggung jawab atas laporan keuangan paragraf 9 (Sembilan) secara implisit menyarankan untuk mengungkapkan tanggung jawab masalah lingkungan dan sosial dalam laporan tambahan mengenai lingkungan hidup dan laporan nilai tambahan (Putri, 2013). Sebuah laporan berkelanjutan harus menyediakan gambaran yang berimbang dan masuk akal dari kinerja keberlanjutan sebuah organisasi. Namun pada kenyaataannya pengungkapan sustainability report (SR) di kebanyakan negara, termasuk Indonesia masih bersifat voluntary artinya perusahaan dengan sukarela menerbitkannya dan tidak ada aturan yang mewajibkan seperti halnya pada penerbitan financial reporting (Utama,2006 dalam Azwir,2014). Adanya alasan tersebut, tidak membuat semua perusahaan di Indonesia melakukan pengungkapan sustainability report, tidak adanya single definition dari sustainability reporting yang mampu diterima secara global, maupun bagaimana seharusnya bentuk format dari sustainability report itu sendiri menjadi alasan utama tidak setiap perusahaan mau melakukan pengungkapan (Dilling, 2009 dalam Mega,2013).

Pengungkapan laporan keberlanjutan (Sustainability Report) semakin mendapat perhatian dalam praktek bisnis global dan menjadi salah satu kriteria dalam menilai tanggung jawab sosial suatu perusahaan. Para pemimpin perusahaan-perusahaan dunia semakin menyadari bahwa pengungkapan laporan yang lebih komprehensif (tidak hanya sekedar laporan keuangan) akan mendukung strategi perusahaan. Pengungkapan Sustainability Report juga dapat meningkatkan kinerja keuangan dan membangun legitimasi perusahaan.

Berbagai penelitian yang pernah dilakukan berkaitan dengan Sustainability Report diantaraya pada penelitian yang dilakukan Mega (2013) variabel dewan komisaris memiliki pengaruh terhadap sustainability report, 
berbeda dengan Ati Ratna (2013) yang menyatakan bahwa dewan komisaris tidak berpengaruh terhadap sustainability report. Variabel komite audit dalam penelitian yang dilakukan Mega (2013) menyatakan bahwa komite audit berpengaruh terhadap sustainability report, sedangkan dalam penelitian Azwir,dkk (2014) menyatakan bahwa komite audit tidak berpengaruh terhadap sustainability report .

ROA berpengaruh terhadap sustainability report, Mega (2013). Hal ini sejalan dengan penelitian yang dilakukan Azwir,dkk (2014). Hasil penelitian berbeda dengan Luciana (2014) yang menyatakan bahwa ROA tidak memiliki pengaruh terhadap sustainability report. Leverage berpengaruh terhadap sustainability report, dalam penelitian yang dilakukan oleh Azwir,dkk (2014). Berbeda dengan hasil penelitian yang dilakukan oleh Mega (2013) dan Luciana (2014) yang menyatakan bahwa leverage tidak berpengaruh terhadap sustainability report

Variabel ukuran perusahaan (size) berpengaruh terhadap sustainability report, dalam penelitian Luciana (2008). Hal ini tidak sejalan dengan penelitian yang dilakukan Mega (2013), Ati (2013), dan Azwir,dkk (2014) yang menyatakan size tidak berpengaruh terhadap sustainability report.

Dari beberapa penelitian yang telah dilakukan, masih terdapat perbedaan hasil penelitian antara peneliti satu dengan peneliti yang lain berkaitan dengan Sustainability Report. Oleh karena itu peneliti tertarik untuk melakukan penelitian kembali mengenai pengaruh Dewan Komisaris, Komite Audit,ROA,Leverage, dan ukuran perusahaan terhadap pengungkapan Sustainability Report.

\section{TELAAH PUSTAKA}

Dalam suatu perusahaan selalu menerbitkan laporan keuangan untuk mengundang investor yang masuk atau informasi kepada publik. Perusahaan tidak hanya menerbitkan laporan keuangan saja, ada juga perusahaan yang menerbitkan laporan tentang kepedulian sosial dan lingkungan.

Sustainability report memiliki definisi yang beragam, menurut Elkington, 1997 dalam Adhima, 2013 Sustainability Report (SR) berarti laporan yang memuat tidak saja informasi kinerja keuangan tetapi juga informasi non keuangan yang terdiri dari informasi aktivitas sosial dan lingkungan yang memungkinkan 
perusahaan bisa bertumbuh secara berkesinambungan (sustainable performance). Manfaat SR yang berdasarkan pada kerangka GRI, yaitu:

1. Sebagai benchmark kinerja organisasional dengan memperhatikan hukum, norma, undang-undang, standar kinerja, dan prakarsa sukarela

2. Mendemostrasi komitmen organisasional untuk sustainable development

3. Membandingan kinerja organisasional setiap waktu.

\section{Hubungan Dewan Komisaris dengan Sustainability Report}

Komisaris independen merupakan pihak yang tidak mempunyai hubungan bisnis dan kekeluargaan dengan pemegang saham pengendali, anggota direksi dan dewan komisaris, serta dengan perusahaan itu sendiri (KNKG,2006). Mulyadi, (2002) dalam Mega (2013) menyatakan bahwa Dewan komisaris bertanggung jawab untuk menentukan apakah manajemen memenuhi tanggung jawab mereka dalam mengembangkan dan menyelenggarakan pengendalian intern. Semakin besar atau dominan proporsi dewan komisaris dalam perusahaan dapat memberikan power untuk menekan manajemen dalam meningkatkan kualitas pengungkapan pelaporan perusahaan. Peningkatan kualitas pengungkapan pelaporan ini, akan membuat perusahaan mengungkapkan informasi seluas-luasnya termasuk informasi tambahan seperti sustainability report yang dilakukan oleh pihak manajemen. Jika citra perusahaan meningkat, maka hal tersebut menandakan pengawasan yang baik dari dewan komisaris dan kerja manajemen yang efektif. Mega (2013) mendapatkan hasil dewan komisaris berpengaruh terhadap sustainability report. Berdasarkan penjelasan diatas, maka hipotesis yang diajukan : H1 : Dewan komisaris berpengaruh terhadap pengungkapan Sustainability report.

\section{Hubungan Komite Audit dengan Sustainability Report}

Mulyadi (2002) dalam Mega (2013) menjelaskan bahwa komite audit memiliki tugas untuk menelaah kebijakan akuntansi yang diterapkan perusahaan, menilai pengendalian internal, menelaah sistem pelaporan kepada pihak eksternal dan kepatuhan terhadap pihak eksternal. Keberadaan komite audit akan mendorong perusahaan untuk menerbitkan laporan yang 
lengkap dan berintegritas tinggi. Collier (dalam Hari Suryono (2011) menyatakan bahwa keberadaan komite audit membantu menjamin pengungkapan dan sistem pengendalian akan berjalan dengan baik. Dengan frekuensi rapat komite audit yang semakin sering, maka pengawasan yang dilakukan akan semakin baik dan kualitas pengungkapan informasi sosial yang dilakukan semakin luas. Berdasarkan hasil penelitian yang dilakukan Mega (2013) ,komite audit berpengaruh terhadap sustainability report. Berdasarkan penjelasan diatas, maka hipotesis yang diajukan :

H2 : Komite Audit berpengaruh terhadap pengungkapan Sustainability Report

\section{Hubungan Profitabilitas dengan Sustainability Report}

Profitabilitas merupakan ukuran yang digunakan untuk mengetahui kemampuan perusahaan dalam menghasilkan laba. Profitabilitas dapat diproksikan dengan ROA. Semakin tinggi rasio profitabilitas, maka semakin tinggi pula informasi yang diberikan oleh manajer. Hal ini dikarenakan pihak manajemen ingin meyakinkan investor mengenai profitabilitas dan kompetensi manajer. Beberapa penelitian menunjukkan bahwa profitabilitas perusahaan merupakan indikator pengelolaan manajemen perusahaan yang baik, sehingga manajemen akan cenderung mengungkapkan lebih banyak informasi ketika ada peningkatan profitabilitas perusahaan. Penelitian yang dilakukan Azwir, (2014) dan Mega (2013) mendapatkan hasil ROA berpengaruh terhadap sustainability report. Berdasarkan penjelasan diatas, maka hipotesis yang diajukan :

$\mathrm{H} 3$ : profitabilitas (ROA) berpengaruh terhadap pengungkapan sustainability report

\section{Hubungan Leverage dengan Sustainability Report}

Tingkat leverage yang tinggi berarti perusahaan mempunyai proporsi hutang yang besar (Jensen dan Meckling,1976 dalam Luciana, 2008) menyatakan bahwa perusahaan dengan tingkat leverage yang tinggi akan menanggung monitoring cost yang juga tinggi. Hal ini dapat mempengaruhi manajemen perusahaan untuk melaporkan tingkat profitabilitas yang tinggi dengan mengurangi biaya-biaya termasuk biaya untuk mengungkapkan laporan tanggung jawab sosial dan lingkungan. Perusahaan dalam mempublikasikan sustainability report 
memerlukan waktu yang panjang dan biaya yang cukup besar, sehingga perusahaan akan mengurangi tingkat pengungkapan laporan yang bersifat sukarela terlebih terpisah dari annual report. Penelitian yang dilakukan Azwir (2014) mendapatkan hasil leverage berpengaruh terhadap sustainability report. Berdasarkan penjelasan diatas, maka hipotesis yang diajukan :

H4 : Tingkat leverage berpengaruh terhadap pengungkapan sustainability report.

\section{Hubungan Ukuran Perusahaan (Size) dengan Sustainability Report}

Perusahaan dengan ukuran yang besar lebih banyak mendapat sorotan dari publik. Maka dari itu, perusahaan yang besar cenderung lebih banyak mengeluarkan biaya untuk mengungkapkan informasi yang lebih luas seperti informasi tambahan berupa sustainability report. Hal ini dilakukan sebagai upaya untuk menjaga legitimasi perusahaan. Legitimasi perusahaan dapat diwujudkan melalui pengungkapan, akan mengungkapkan bagaimana tanggung jawab perusahaan atas aktivitas yang telah dilakukan. Penelitian yang dilakukan oleh Sembiring (2005) dalam Mega (2013) menemukan adanya pengaruh positif ukuran perusahaan terhadap pengungkapan tanggung jawab sosial perusahaan. Berdasarkan penjelasan diatas, maka hipotesis yang diajukan :

H5: Ukuran perusahaan berpengaruh terhadap pengungkapan sustainability report.

Berdasarkan teori yang telah dijelaskan diatas dan hasil dari penemuan peneliti terdahulu tentang variabel-variabel yang mempengaruhi pengungkapan Sustainability Report maka pemaparan kerangka pemikiran ini akan menjelaskan mengenai pengaruh Dewan Komisaris, Komite Audit, ROA, Leverage dan Size terhadap Sustainabilty Report. Yang dapat disajikan pada gambar berikut : 


\section{Gambar 1}

Kerangka pemikiran

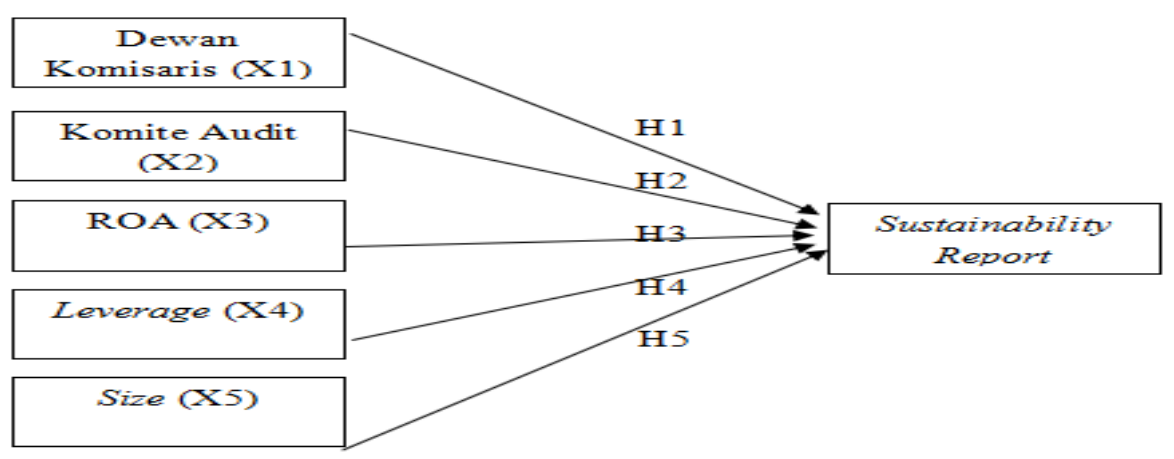

\section{METODE PENELITIAN}

\section{Variabel Penelitian}

Variabel depeden dalam penelitian ini adalah pengungkapan Sustainability Report. Pengungkapan sustainability report diukur dengan menggunakan variabel dummy, pengukuran dilakukan dengan memberikan nilai 1 untuk perusahaan yang melakukan dan mengungkapkan sustainability report dan 0 untuk perusahaan yang tidak melakukan dan mengungkapkan sustainability report. Variabel independen dalam penelitian ini terdiri dari :

1. Dewan Komisaris diukur dengan menghitung jumlah seluruh anggota dewan komisaris dalam suatu perusahaan yang terdapat dalam laporan tahunan perusahaan.

2. Komite Audit diukur dengan menghitung jumlah seluruh anggota komite audit dalam suatu perusahaan yang terdapat dalam laporan tahunan perusahaan.

3. Profitabilitas (ROA) diukur dengan menghitung rumus laba bersih setelah pajak dibagi dengan total asset

4. Leverage diukur dengan debt to ratio (DER) yaitu dengan menggunakan rumus total liabilitas dibagi dengan total ekuitas.

5. Ukuran perusahaan diukur dengan menghitung logoritma natural (LN) dari total asset yang dimiliki perusahaan.

\section{Penentuan Sampel}

Populasi dari penelitian ini yaitu seluruh perusahaan yang terdaftar di Bursa Efek Indonesia pada Tahun 2010-2014. Teknik pengambilan sampel yang digunakan dalam penelitian ini adalah metode purposive sampling, yaitu 
pengambilan sampel yang dilakukan penulis melalui pertimbangan dan dengan berdasarkan kriteria tertentu. Kriteria yang digunakan dalam pemilihan sampel penelitian ini antara lain adalah sebagai berikut :

1. Perusahaan yang menjadi sampel adalah seluruh perusahaan di Indonesia yang terdaftar di BEI selama periode 2010-2014.

2. Perusahaan yang menerbitkan laporan keuangan secara berturut-turut selama periode $2010-2014$

3. Perusahaan yang menyajikan laporan keuangan dalam mata uang rupiah selama periode penelitian

4. Perusahaan yang mempublikasikan Sustainability Report dan memiliki kelengkapan data untuk kebutuhan penelitian

Berdasarkan metode dan kriteria - kriteria yang telah ditentukan diatas, maka diperoleh sampel sebanyak 39 perusahaan.

\section{Jenis, Sumber, dan Metode Pengumpulan Data}

Jenis data yang digunakan dalam penelitian ini yaitu data sekunder.

Sumber data dalam penelitian ini yaitu Indonesia Capital Market Directory (ICMD), IDX Statistik, NCSR( National Center for Sustainability Report) Laporan Keuangan secara lengkap selama periode 2010-2014. Pengumpulan data yang dilakukan dengan metode dokumentasi kemudian peneliti melakukan pengumpulan data sekunder yang dipakai seperti Capital Market Directory (ICMD), IDX statistik, NCSR( National Center for Sustainability Report) Laporan Keuangan secara lengkap selama periode 2010-2014.

\section{Metode Analisis}

Dalam penelitian ini metode analisis data yang digunakan adalah metode regresi logistik (logistic regression), Persamaan regresi logistic tersebut dirumuskan sebagai berikut:

$$
\mathrm{Y}=\mathrm{a}+\mathrm{b} 1 \mathrm{X} 1+\mathrm{b} 2 \mathrm{X} 2+\mathrm{b} 3 \mathrm{X} 3+\mathrm{b} 4 \mathrm{X} 4+\mathrm{b} 5 \mathrm{X} 5+\mathrm{e}
$$

Keterangan :

$\mathrm{Y}=$ Sustainability Report 


$$
\begin{array}{ll}
\text { X1 } & =\text { Dewan Komisaris } \\
\text { X2 } & =\text { Komite Audit } \\
\text { X3 } & =\text { ROA ( Return On Asset }) \\
\text { X4 } & =\text { Leverage } \\
\text { X5 } & =\text { Size } \\
\mathrm{a} & =\text { Koefisien Konstanta } \\
1,2,3 & =\text { Koefisien Regresi } \\
\mathrm{e} & =\text { Variabel gangguan/error }
\end{array}
$$

\section{HASIL DAN PEMBAHASAN}

\section{Statistik Deskriptif}

Berdasarkan metode purposive sampling diperoleh hasil sejumlah 39 perusahaan sampel,sehingga data mentah yang diolah berjumlah 195 (39 x 5 tahun). Dan hasil analisis deskriptif dapat dilihat pada tabel 1.

Tabel 1

Hasil Analisis Deskriptif

\begin{tabular}{|c|c|c|c|c|c|}
\hline \multicolumn{7}{|c|}{ Descriptive Statistics } \\
\hline & $\mathrm{N}$ & Minimum & Maximum & Mean & Std. Deviation \\
\hline SR & 195 & .00 & 1.00 & .9128 & .28282 \\
\hline DEKOM & 195 & 2.00 & 12.00 & 5.9179 & 1.93541 \\
\hline KOMDIT & 195 & 2.00 & 8.00 & 3.8462 & 1.18275 \\
\hline ROA & 195 & -.06 & .42 & .0971 & .10014 \\
\hline LEVERAGE & 195 & -4.76 & 18.19 & 2.8148 & 3.54509 \\
\hline SIZE & 195 & 11.52 & 30.51 & 20.5094 & 4.88633 \\
\hline Valid N (listwise) & 195 & & & & \\
\hline
\end{tabular}

Sumber :Hasil olah data, 2016

Berdasarkan hasil perhitungan deskriptif pada tabel diatas, dapat dijelaskan sebagai berikut :

1. Sustainability Report mempunyai nilai minimum 0.00 yang artinya perusahaan yang tidak melakukan pengungkapan sustainability report diberikan scor minimum 0,00 sedangkan nilai maksimum 1,00 yang berarti perusahaan telah melakukan pengungkapan sustainability report dengan 
memberikan scor maksimum 1,00 rata-rata nilai variabel sustainability report sebesar 0.9128 dan standar deviasi sebesar 0.28282

2. Dewan Komisaris mempunyai nilai minimum 2,00, yang artinya jumlah atau komposisi dewan komisaris paling sedikit yang terdapat di perusahaan ada 2 orang sedangkan nilai maximum 12,00 yang berarti jumlah atau komposisi dewan komisaris paling banyak yang terdapat di perusahaan sebanyak 12 orang. Rata-rata nilai variabel dewan komisaris dalam penelitian ini adalah sebesar 5.9179 dan standar deviasi sebesar 1.93541

3. Komite Audit mempunyai nilai minimum 2,00, yang artinya jumlah atau komposisi komite audit paling sedikit yang terdapat di perusahaan ada 2 orang, sedangkan nilai maximum 8,00 yang berarti jumlah atau komposisi komite audit paling banyak yang terdapat di perusahaan sebanyak 8 orang. Rata-rata nilai variabel komite audit dalam penelitian ini adalah sebesar 3.8462 dan standar deviasi sebesar 1.18275

4. Profitabilitas yang diproksikan dengan ROA mempunyai nilai minimum -0.06, yang artinya perusahaan tidak mengoptimalkan labanya atas asset yang dimiki, sedangkan nilai maximum 0,42 yang berarti perusahaan dapat mengoptimalkan labanya atas asset yang dimiki dengan nilai maksimum sebesar 0,42 rata-rata nilai variabel ROA sebesar 0.0971 dan standar deviasi sebesar 0.10014

5. Leverage diukur dengan DER (debt to equity ratio) mempunyai nilai minimum -4.76 yang artinya proporsi hutang yang dilakukan perusahaan paling sedikit sebesar -4.76 sedangkan nilai maximumnya sebesar 18.19 yang berarti proporsi hutang yang dilakukan perusahaan paling banyak sebesar 18.19 rata-rata nilai variabel leverage sebesar 2.8148 dan standar deviasi sebesar 3.54509

6. Ukuran perusahaan mempunyai nilai minimum 11.52, yang artinya ukuran perusahaan paling kecil sebesar 11.52 sedangkan nilai maksimum 30.51 yang berarti skala ukuran perusahaan paling besar adalah 30.51 rata-rata nilai variabel ukuran perusahaan sebesar 20.5094 dan standar deviasi sebesar 4.88633 


\section{Menguji Keseluruhan Model (Overal Model Fit Test)}

Pengujian keseluruhan model dilakukan dengan membandingkan nilai antara -2 Log Likelihood (-2LL) pada awal (Block Number $=0$ ), dimana model hanya memasukkan konstanta dengan nilai -2 Log Likelihood (-2LL) pada akhir (Block Number $=1$ ), dimana model memasukkan konstanta dan variabel bebas. Penurunan likelihood (-2LogL) menunjukkan model regresi yang lebih baik atau dengan kata lain model yang dihipotesiskan fit dengan data. Hasil uji fit dapat dilihat pada tabel 2, sebagai berikut :

Tabel 2

Hasil Uji Model Fit 1

\begin{tabular}{|c|c|c|c|}
\hline \multicolumn{3}{|c|}{ Iteration Historya,b,c } \\
\hline \multirow{2}{*}{ Iteration } & & Coefficients \\
\cline { 3 - 4 } & $-2 \log$ likelihood & Constant \\
\hline Step 0 & 1 & 124.576 & 1.651 \\
\cline { 2 - 4 } & 2 & 115.795 & 2.197 \\
\cline { 2 - 4 } & 3 & 115.427 & 2.340 \\
\cline { 2 - 4 } & 4 & 115.426 & 2.349 \\
\cline { 2 - 4 } & 5 & 115.426 & 2.349 \\
\hline
\end{tabular}

Sumber :Hasil olah data, 2016

Tabel 3

Hasil Uji Model Fit 2

\begin{tabular}{|c|c|c|c|c|c|c|c|c|}
\hline \multicolumn{9}{|c|}{ Iteration Historya,b,c,d } \\
\hline \multirow{2}{*}{ Iteration } & \multirow{2}{*}{$\begin{array}{c}-2 \text { Log } \\
\text { likelihood }\end{array}$} & \multicolumn{7}{c|}{ Coefficients } \\
\cline { 4 - 9 }$y$ & Constant & X1 & X2 & X3 & X4 & X5 \\
\hline \multirow{3}{*}{ Step 1 } & 1 & 121.487 & 2.694 & .035 & -.102 & -.727 & -.013 & -.037 \\
\cline { 2 - 9 } & 2 & 109.668 & 4.488 & .096 & -.234 & -1.615 & -.032 & -.081 \\
\cline { 2 - 9 } & 3 & 108.132 & 5.525 & .170 & -.346 & -2.268 & -.052 & -.114 \\
\cline { 2 - 9 } & 4 & 108.053 & 5.757 & .200 & -.380 & -2.432 & -.059 & -.122 \\
\cline { 2 - 9 } & 5 & 108.053 & 5.770 & .202 & -.382 & -2.442 & -.059 & -.122 \\
\cline { 2 - 9 } & 6 & 108.053 & 5.770 & .202 & -.382 & -2.442 & -.059 & -.122 \\
\hline
\end{tabular}

Sumber :Hasil olah data, 2016

Dari tabel 2 dan tabel 3 hasil perhitungan nilai -2LL terlihat bahwa nilai blok pertama (Block Number $=0$ ) adalah 124.576 dan nilai -2LL pada blok kedua (Block Number $=1$ ) adalah sebesar 108.053 Hal ini menunjukkan terjadinya penurunan nilai -2Log Likelihood adalah sebesar $124.576-108.053=16.523$. 
Penurunan likelihood menunjukkan model regresi yang baik atau dengan kata lain model yang dihipotesiskan fit dengan data.

\section{Koefisien Determinasi (Nagelkerke R Square)}

Koefisien determinasi digunakan untuk melihat seberapa besar variabel independen mampu menjelaskan variabel dependen. Tabel 4 menunjukkan nilai Nagelkerke $R$ Square adalah sebesar 0.083 yang berarti variabel independen yaitu variabel dewan komisaris, komite audit, ROA, leverage dan ukuran perusahaan mampu menjelaskan variabel sustainability report sebesar $8,3 \%$.

Tabel 4

Hasil Uji Model Summary

\begin{tabular}{|r|r|r|r|}
\hline \multicolumn{4}{|c|}{ Model Summary } \\
\hline Step & $\begin{array}{c}-2 \text { Log } \\
\text { likelihood }\end{array}$ & $\begin{array}{c}\text { Cox \& Snell R } \\
\text { Square }\end{array}$ & $\begin{array}{c}\text { Nagelkerke } \\
\text { R Square }\end{array}$ \\
\hline 1 & $108.053 \mathrm{a}$ & .037 & .083 \\
\hline
\end{tabular}

Sumber :Hasil olah data, 2016

\section{Hasil Uji Kelayakan Model Regresi (Hosmer and Lemeshow's Test Goodness of} Fit Test)

Kelayakan model regresi diuji dengan menggunakan Hosmer and Lemeshow's Test Goodness of Fit Test. Hosmer and Lemeshow's Goodness of Fit Test menguji hipotesis nol bahwa data empiris cocok atau sesuai dengan model. Hasil uji Hosmer and Lemeshow's Test Goodness of Fit Test dapat dilihat pada tabel 5 sebagai berikut :

Tabel 5

Hasil Uji Hosmer and Lemeshow's Test Goodness of Fit Test

\begin{tabular}{|c|c|c|c|}
\hline \multicolumn{4}{|c|}{ Hosmer and Lemeshow Test } \\
\hline Step & Chi-square & df & Sig. \\
\hline 1 & 5.229 & 8 & .733 \\
\hline
\end{tabular}

Dari hasil pengujian pada tabel diatas diperoleh nilai Chi-square sebesar 5.229 dengan nilai signifikan 0.733 dan derajat bebas (df) 8. Dari hasil tersebut terlihat bahwa nilai signifikan lebih besar 0.05. Sehingga dapat disimpulkan bahwa 
pada model regresi yang telah digunakan dapat diterima karena cocok dengan data observasinya.

\section{Hasil Pengujian Secara Parsial}

Penelitian ini menggunakan teknik analisis data dengan menggunakan regresi logistik untuk mengetahui pengaruh secara parsial masing-masing variabel independen terhadap variabel dependen. Berdasarkan hasil pengujian dengan menggunakan SPSS versi 16.0 menghasilkan output sebagai berikut :

Tabel 6

Hasil Uji Secara Parsial

Hasil Uji Secara Parsial

\begin{tabular}{|c|c|c|c|c|c|c|c|}
\hline \multicolumn{8}{|c|}{ Variables in the Equation } \\
\hline \multirow{3}{*}{ Step 1a } & $\mathrm{X} 1$ & .202 & .194 & 1.083 & 1 & .298 & 1.224 \\
\cline { 2 - 8 } & $\mathrm{X} 2$ & -.382 & .249 & 2.364 & 1 & .124 & .682 \\
\cline { 2 - 8 } & $\mathrm{X} 3$ & -2.442 & 2.909 & .705 & 1 & .401 & .087 \\
\cline { 2 - 8 } & $\mathrm{X} 4$ & -.059 & .082 & .514 & 1 & .473 & .943 \\
\cline { 2 - 8 } & $\mathrm{X} 5$ & -.122 & .062 & 3.948 & 1 & .047 & .885 \\
\cline { 2 - 7 } & Constant & 5.770 & 2.204 & 6.852 & 1 & .009 & 320.572 \\
\hline
\end{tabular}

Berdasarkan tabel 6 diatas maka model regresi logistik yang diperoleh adalah sebagai berikut :

$$
\begin{aligned}
\mathrm{SR}= & 5.770+0.202 \text { DEWAN KOMISARIS }-0.382 \text { KOMITE AUDIT }-2.442 \\
& \text { ROA }-0.059 \text { LEVERAGE }-0.122 \text { SIZE }+\mathrm{e}
\end{aligned}
$$

Pengujian hipotesis ini dilakukan dengan cara membandingkan antara tingkat signifikansi (sig) dengan tingkat kesalahan $(\alpha)=5 \%$. Berdasarkan Tabel 6 dapat diinterpretasikan hasil sebagai berikut :

1. Pengujian hipotesis pertama (H1)

Hipotesis pertama menyatakan bahwa variabel dewan komisaris tidak berpengaruh terhadap sustainability report. Hasil pengujian pada tabel 4.7 bahwa variabel dewan komisaris menunjukkan nilai signifikansi sebesar 0.298 lebih besar dari 5\%, maka dapat disimpulkan bahwa variabel dewan komisaris 
tidak berpengaruh terhadap sustainability report atau hipotesis pertama (H1) ditolak.

2. Pengujian hipotesis kedua $(\mathrm{H} 2)$

Hipotesis kedua menyatakan bahwa variabel komite audit tidak berpengaruh terhadap sustainability report. Hasil pengujian pada tabel 4.7 bahwa variabel komite audit menunjukkan nilai signifikansi sebesar 0.124 , lebih besar dari 5\%, maka dapat disimpulkan bahwa variabel komite audit tidak berpengaruh terhadap sustainability report atau hipotesis kedua (H2) ditolak.

3. Pengujian hipotesis ketiga (H3)

Hipotesis ketiga menyatakan bahwa variabel ROA tidak berpengaruh terhadap sustainability report. Hasil pengujian pada tabel 4.7 bahwa variabel ROA menunjukkan nilai signifikansi sebesar 0.401 lebih besar dari 5\%, maka dapat disimpulkan bahwa variabel ROA tidak berpengaruh terhadap sustainability report atau hipotesis ketiga (H3) ditolak.

4. Pengujian hipotesis keempat $(\mathrm{H} 4)$

Hipotesis keempat menyatakan bahwa variabel leverage tidak berpengaruh terhadap sustainability report. Hasil pengujian pada tabel 4.7 bahwa variabel leverage menunjukkan nilai signifikansi sebesar 0.473 lebih besar dari 5\%, maka dapat disimpulkan bahwa variabel leverage tidak berpengaruh terhadap sustainability report atau hipotesis ketiga (H4) ditolak.

5. Pengujian hipotesis kelima (H5)

Hipotesis kelima menyatakan bahwa variabel ukuran perusahaan berpengaruh terhadap sustainability report. Hasil pengujian pada tabel 4.7 bahwa variabel ukuran perusahaan menunjukkan nilai signifikansi sebesar 0.047 lebih kecil dari 5\%, maka dapat disimpulkan bahwa variabel ukuran perusahaan berpengaruh terhadap sustainability report atau hipotesis kelima (H5) diterima.

PEMBAHASAN

\section{Pengaruh Dewan Komisaris Terhadap Sustainability Report}

Hasil uji regresi logistik menunjukkan bahwa dewan komisaris tidak berpengaruh terhadap pengungkapan sustainability report. Berdasarkan hasil 
penelitian periode 2010-2014 seperti pada PT. Indofarma tbk yang memiliki proporsi dewan komisaris yang terus - menerus menurun dari tahun ke tahun. Dimulai dari tahun 2010 sampai 2011 sejumlah 5 orang, hingga di tahun 2014 menjadi 3 orang. Selama periode penelitian yaitu selama tahun 2010 hingga 2014 perusahaan tersebut tidak selalu melakukan pengungkapan sustainability report. Hasil tersebut menunjukan bahwa keberadaan dewan komisaris dalam suatu perusahaan belum tentu berpengaruh dalam pemantauan kualitas pelaporan yang dilakukan pihak manajemen dalam pengungkapan financial dan tanggung jawab sosial perusahaan. Hal ini sejalan dengan dengan penelitian Ati (2013) yang mendapatkan hasil dewan komisaris tidak berpengaruh terhadap sustainability report. Sedangkan penelitian Hari Suryono (2011) mendapatkan hasil dewan komisaris berpengaruh terhadap sustainability report.

\section{Pengaruh Komite audit Adit Terhadap Sustainability report}

Hasil penelitian menyatakan bahwa komite audit tidak berpengaruh terhadap sustainability report. Ditolaknya hipotesis ini adalah dimungkinkan karena jumlah anggota komite audit yang dimiliki perusahaan hanya sebagai formalitas untuk memenuhi peraturan yang ditetapkan oleh Pemerintah, tanpa mempertimbangkan efektivitas dan kompleksitas perusahaan. Hal ini seperti yang dilakukan PT.Jasuindo tiga perkasa tbk yang memberikan jumlah audit rata-rata dari tahun 2010 hingga 2014 sebanyak 3 orang atau dapat dikatakan ukuran komite audit perusahaan masih rendah, sehingga belum mampu mempengaruhi luas pengungkapan tanggung jawab sosial perusahaan. Berdasarkan hasil penelitian, hal ini sejalan dengan penelitian yang dilakukan Azwir N(2014) bahwa komite audit tidak berpengaruh terhadap sustainability report. Sedangkan,Mega (2013) menyatakan bahwa komite audit berpengaruh terhadap sustainability report.

\section{Pengaruh Profitabilitas Terhadap Sustainability report}

Hasil penelitian menunjukkan ROA tidak mempengaruhi keputusan perusahaan untuk melakukan sustainability report. Seperti yang dilakukan oleh PT.Jasuindo tiga perkasa,tbk dimana profitabilitas perusahaan mempuyai nilai yang cukup tinggi selama periode penilitian, dengan nilai ROA sebesar 32\% pada tahun 2010 dan 26\% di tahun 2011 namun dengan meningkatnya profitabilitas 
tersebut belum dapat mempengaruhi keputusan perusahaan untuk melakukan pengungkapan sustainability report. Profitabilitas adalah faktor yang memberikan kebebasan dan fleksibilitas kepada manajemen untuk melakukan dan mengungkapkan program tanggung jawab sosial secara luas. Berdasarkan hasil penelitian, hal ini sejalan dengan penelitian yang dilakukan oleh Luciana (2008) yang menyatakan bahwa ROA tidak berpengaruh terhadap sustainability report. Sedangkan penelitian yang dilakukan Azwir, (2014) dan Mega (2013) mendapatkan hasil ROA berpengaruh terhadap sustainability report.

\section{Pengaruh Leverage Terhadap Sustainability report}

Hasil penelitian ini tidak membuktikan adanya pengaruh leverage terhadap sustainability report. Tingkat leverage yang tinggi dapat diartikan bahwa perusahaan memiliki tingkat hutang yang besar. Hal ini seperti yang yang dilakukan oleh PT Adira Dinamika Multi Finance Tbk pada tahun 2012 memiliki nilai leverage sebesar 4.06 namun pada tahun tersebut perusahaan tidak melakukan pengungkapan sustainability report. Adanya tingkat leverage yang tingi pada perusahaan juga meningkatkan kecenderungan perusahaan untuk melanggar perjanjian kredit sehingga perusahaan akan melaporkan laba sekarang lebih tinggi.Hal ini dapat mempengaruhi manajemen perusahaan untuk melaporkan tingkat profit yang tinggi dengan mengurangi biaya-biaya termasuk biaya untuk mengungkapkan laporan pertanggung jawaban sosial dan lingkungan karena perusahaan dalam mempublikasikan sustainability report memerlukan waktu yang panjang dan biaya yang cukup besar. Dari hasil penelitian, hal ini sejalan dengan penelitian Luciana (2008) yang menyatakan bahwa leverage tidak berpengaruh terhadap sustainability report berbeda dengan Azwir, (2014) yang menyatakan leverage berpengaruh terhadap sustainability report.

\section{Pengaruh Ukuran Perusahaan Terhadap Sustainability report}

Hasil penelitian menunjukkan bahwa ukuran perusahaan memiliki pengaruh dalam pengungkapan sustainability report. Perusahaan dengan ukuran yang besar lebih banyak mendapat sorotan dari publik. Maka dari itu, perusahaan yang besar cenderung lebih banyak mengeluarkan biaya untuk mengungkapkan informasi yang lebih luas seperti pada pengungkapan Sustainability report sebagai 
upaya untuk menjaga legitimasi perusahaan. Hal ini dapat diinterpestasikan seperti pada PT Bakriland Development Tbk dilihat dari LN Total Asset, perusahaan menunjukan nilai rata-rata size sebesar 30 selama periode penelitian. Hasil ini mengindikasikan bahwa semakin besar perusahaan dapat menunjukkan semakin luas perusahaan tersebut melakukan pengungkapan sustainability report. Hasil penelitian ini sesuai dengan hasil penelitian Luciana (2008) yang menyatakan ukuran perusahaan berpengaruh tehadap sustainability report. Sedangkan Azwir (2014), Mega (2013) dan Ati (2013) yang menyatakan bahwa ukuran perusahaan tidak berpengaruh terhadap sustainability report.

\section{KESIMPULAN DAN KETERBATASAN}

Berdasarkan hasil analisis mengenai faktor-faktor yang bepengaruh terhadap pengungkapan sustainability report,maka diperoleh kesimpulan sebagai berikut :

1. Dewan Komisaris tidak berpengaruh terhadap pengungkapan sustainability report

2. Komite Audit tidak berpengaruh terhadap pengungkapan sustainability report

3. ROA tidak berpengaruh terhadap pengungkapan sustainability report

4. Leverage tidak berpengaruh terhadap pengungkapan sustainability report

5. Ukuran Perusahaan berpengaruh terhadap pengungkapan sustainability report

Saran yang dapat diberikan berkaitan dengan hasil penelitian ini dapat dijelaskan sebagai berikut :

1. Untuk Perusahaan

Hendaknya perusahaan melakukan pengungdewan komisarisan informasi sustainability report yang mengedepankan akuntanbilitas dan transpanrasi kegiatan Corporate Social Responsibility (CSR) yang dilakukan perusahaan dengan menitikberatkan pada pertanggungjawaban ekonomi, sosial, dan lingkungan kepada stakeholder. Dengan begitu diharapkan akan membuat perusahaan dapat terus-menerus tumbuh dan berkembang secara berkesinabumgan. 
2. Untuk Investor

Sebagai referensi informasi dalam pengambilan keputusan dalam berinvestasi perusahaan mana yang melakukan pengungdewan komisarisan Sustainability report yang dapat digunakan sebagai alat analisis kinerja perusahaan selain annual report.

3. Untuk Pemerintah

Sebagai kajian dalam penetapan peraturan dan kebijakan tentang sustainability report di Indonesia, dimana Indonesia belum memiliki peraturan dan kebijakan mengenai praktik pengungdewan komisarisan sustainability report .

Dalam penelitian ini terdapat kelemahan dan keterbatasan yang memerlukan penyempurnaan dimasa yang akan datang, yaitu :

1. Berdasarkan hasil koefisien determinasi yang menunjukan nilai Nagelkerke R-Squere adalah sebesar 0.083 , hal ini berarti 8,3\% variabel Sustainability Report dapat dijelaskan oleh lima variabel independen yaitu Dewan Komisaris, Komite Audit, ROA, Leverage, dan Size Sedangkan sisanya $(100 \%-8,3 \%=$ $91,7 \%$ ) dijelaskan oleh sebab-sebab yang lain diluar variabel-variabel dalam penelitian ini.

2. Sampel dan obyek penelitian ini masih terbatas, sehinnga penelitian yang dilakukan hanya 39 perusahaan dengan jumlah data yang diolah 195

\section{Agenda Penelitian Selanjutnya}

Bagi peneliti selanjutnya sebaiknya memperpanjang periode penelitian agar dapat terlihat kecenderungan dalam jangka panjang dan dapat memperbanyak observasi. Selain itu sebaiknya menambah atau mengganti variabel lain yang belum dimasukkan dalam penelitian ini yang memiliki pengaruh terhadap pengungkapan Sustainability Report

\section{DAFTAR PUSTAKA}

Anggraini, devi. 2014. Pengaruh Corporate Governance Terhadap Luas Pengungkapan Corporate Social Responsibility di Dalam Sustainability Repor. Fakultas Ekonomi, Universitas Riau 
Aulia , Adistira Sri dan dhaniel. 2013. Pengaruh Karakteristik Perusahaan terhadap Praktek Pengungkapan Sustainability Reporting Dalam LaporanTahunan Perusahaan Publik di Indonesia. Program Studi Akuntansi FE Universitas Muhammadiyah Malang

Ghozali, imam (2011). Aplikasi Analisis Multivariate Dengan Program IBM SPSS 19 (edisi kelima). Semarang : Universitas Diponegoro

Nazir , Azwir, Et Al .2104. Pengaruh Karakteristik Perusahaan Dan Corporate Governance Terhadap Pengungkapan Sustainability Report Pada Perusahaan Lq45 Yang Terdaftar. Jurnal Ekonomi Volume 22, Nomor 1 Maret 2014

Nurrahman, Adimulya Dan Sudarno. 2013. Pengaruh Kepemilikan Manajerial, Kepemilikan Institusional, Dan Kepemilikan Asing Terhadap Praktik Pengungkapan Sustainability Report. Diponegoro Journal Of Accounting Volume 2, Nomor 1, Tahun 2013, Halaman 1-14

Putri , Cynthia Dwi. 2013. Pengaruh Corporate Overnance Dan Karakteristik Perusahaan Terhadap Pengungkapan Tanggung Jawab Sosial Perusahaan Di Dalam Sustainability Report (Studi Empiris Perusahaan Yang Terdaftar Di Bei). Fakultas Ekonomi Universitas Negeri Padang

Sari, Ati Retna. Pengaruh Kepemilikan Institusional, Komposisi Dewan Komisaris, Kinerja Perusahaan Terhadap Luas Pengungkapan Corporate Social Responsibilitydi Dalamsustainability Report Pada Perusahaan Manufaktur Yang Terdaftar Di Bei. Pascasarjana Fakultas Ekonomi Dan Bisnis Universitas Brawijaya

Sari, Mega Putri Yustia, Marsono. Pengaruh Kinerja Keuangan, Ukuran Perusahaan Dan Corporate Governance Terhadap Pengungkapan Sustainability Report. Diponegoro Journal Of Accounting Volume 2, Nomor 3, Tahun 2013, Halaman 1-10 Issn (Online): 2337-3806

Sugiyono, 2012, Statistika Untuk Penelitian,Cetakan Ketujuh, Bandung: CV. Alfabeta 
Sugiyono, 2009, Metode Penelitian Kuantitatif, Kualitatif dan R\&D, Bandung : Alfabeta

Aziz, Abdul. 2014. Analisis Pengaruh Good Corporate Governance (Gcg) Terhadap Kualitas Pengungkapan Sustainability Report (Studi Empiris Pada Perusahaan Di Indonesia Periode Tahun 2011-2012). Jurnal Audit dan Akuntansi Fakultas Ekonomi Universitas Tanjungpura Vol. 3, No. 2, Desember 2014 Hal. 65-84

Adhima, Mochammad Fauzan. 2012. Pengaruh Pengungkapan Sustainability Report Terhadap Profitabilitas Perusahaan Studi Kasus Pada Perusahaan Manufaktur Yang Terdaftar Dalam Bursa Efek Indonesia.

Ratnasari, Yunita. 2012. Pengaruh Corporate Governance Terhadap Luas Pengungkapan Tanggung Jawab Sosial Perusahaan Di Dalam Sustainability Report.

Widianto, Hari Suryono. 2011. Pengaruh Profitabilitas, Likuiditas, Leverage, Aktivitas, Ukuran Perusahaan, Dan Corporate Governance Terhadap Praktik Pengungkapan Sustainability Report ( Studi Pada Perusahaan - Perusahaan Yang Listed (Go-Public) Di Bursa Efek Indonesia (Bei) Periode 2007 - 2009 ) .

Idah. 2013. Corporate Governance Dan Karakteristik Perusahaan Dalam Pengungkapan Sustainability Report. Universitas Negeri Semarang Issn 2252-6765.

Suryono, Hari dan Andi Prastiwi,2011. Pengaruh Karateristik Perusahaan dan Corporate Governance Terhadap Praktik Pengungkapan Sustainability Report. Dalam Simposium Nasional XIV Banda Aceh 21-22 Juli 2011

Kurnianingsih, Heni Triastuti. 2013. Pengaruh Profitabilitas Dan Size Perusahaan Terhadap Corporate Social Responsibility. Jurnal Riset Akuntansi Dan Bisnis Vol. 13 No. 1/ Maret 2013

$\underline{\text { www.idx.co.id }}$ 
Majalah Ilmiah Solusi

Vol. 16, No. 4 Oktober 2018

ISSN : 1412-5331

www.tempo.co.id

www.wikipedia.org

www.globalreporting.org

www.nscr-isra.com 